\title{
Conservation Text for Elementary School Students' Environmental Literacy Enrichment
}

\author{
Tommi Yuniawan ${ }^{1}$, Amin Retnoningsih $^{2}$, Diyamon Prasandha ${ }^{3}$ \\ \{tommiyuniawan@mail.unnes.ac.id ${ }^{1}$,aminretnoningsih2016@mail.unnes.ac.id ${ }^{2}$ \\ ,diyamonprasandha@gmail.com ${ }^{3}$ \} \\ ${ }^{1,2,3}$ Universitas Negeri Semarang, Gunungpati, Semarang, Indonesia
}

\begin{abstract}
This research aims at analyzing the level of necessity for conservation text as elementary school students' literacy enrichment. The theoretical basis used in this research is eco- linguistic. This research employs a study and development method. The research results show that the level of necessity for conservation text for elementary school students' literacy enrichment leads to the following aspects: content, legibility, presentation and graphics, motivation. This conservation text refers to three pillars of conservation, namely: value and character pillar, art and culture pillar and natural resource and environment pillar. Conservation text does not only serve as a lingual structure, but also as cognitive structure and action structure. Environmental literacy may become an indicator of students' ecologic awareness in protecting and preserving the earth since childhood.
\end{abstract}

Keywords: conservation text, elementary school students, environmental literacy.

\section{Introduction}

Based on the information provided, the elementary school students and teachers of Gugus Lingkar UNNES campus did not yet understand and comprehend the conservation terms or lexicons. This will affect students' and teachers' level of environmental literacy. Conservation as actions that directly enhance the chances of habitats and species persisting in the wild [1]. Conservation lexicon is a component of language that includes the wealth of words, phrases or units of language expression that contain information on the meaning of language units that describe conservation pillars which include: value and character, art and culture, and natural resources and environment.

The Elementary School students and teachers of Gugus Lingkar UNNES campus had not yet understood the meaning of conservation pillar lexicon, for example: green architecture, conservation pillar, compost house, green belt, green transport, conservation character, conservation and curriculum. This affects their literacy. As a conservation-insightful university [2]. Mikulik and Babina argue that Higher Education (HE) should have an environmental awareness in order to achieve a sustainable development, hence a safeguard need to be formulated [3]. Literacy means the practice and social relationship associated with knowledge, language, and culture. For these reason, literacy involves a series of learning that enables individuals to achieve knowledge, develop knowledge and participate fully in a limited society and a wider community [4]. 
Further, according to progress in International Reading Literacy Study [5], reading literacy is the ability to understand and use written language form needed by the community and/or those appreciated by individuals. Readers can build the meaning of text in various forms. Readers read to learn, to participate in a community of readers in school and everyday life, and for pleasure. Rokhman emphasizes that literacy includes responses, understanding, and life activities organized and applied through an ongoing learning activity [6]. Similarly, OECD states that reading literacy is constructed with three characteristics, namely (1) the situation, also referred to as a purpose of reading a text, (2) the text, also referred to as a material used in the reading, and (3) aspect, also referred to as a cognitive approach constructed on how readers use texts [7].

In this regard, literacy reading also includes four main studies, namely (1) reading skill; (2) applied and practiced reading texts in certain circumstances; (3) reading process; and (4) the texts used [8]. This means that the readers respond to the texts provided in different ways as they seek to use and understand what they read. The condition that strives to fulfill reader's readiness, requires the availability of a text format reading. The format of reading text refers to a continuity of text reading, unsustainability, or a combination of both. Sustainable text is created from sentences arranged in paragraphs (for example newspaper and novel reports). Unsustainable text, also known as document, consists of a number of lists (e.g.: table, schedule, and form). Mixed text includes both elements of continuous text format and unsupported text format and is commonly used in magazines and web pages. Several texts comprise separate sections paired for a specific event or purpose [9].

Subsequently, the reading texts insightful to the conservation pillar were not considerably available to the students and teachers of UNNES Elementary School. This will result in the lack of information, understanding, and comprehensiveness on the terms or environment's lexicons comprehensively. Environmental literacy is the ability of a person to know, understand, and use texts of a conservative pillar. A text is a concrete form of lingual interaction where people actually use language; whatever is said or written; in the context of operation that is distinguished from the context of a quote, such as the words listed in a dictionary [10]. A text relates to what was actually done, interpreted, and said by a community in real situations. Capra insists on the term ecoliteration. Ecoliteration describes a community's high awareness on the importance of an environment with all its contents that must be maintained, preserved, and wisely utilized [11].

Several relevant researches are employed in our literature review, namely: Krishnakumar and Jayakumar [12]; Mbete [13]; Yuniawan, Masrukhi, Urip, Ahmad, Yudhi [14]; Yuniawan, Retnoningsih, Siroj [15]. A study on the development of teaching materials was conducted by Krishnakumar and Jayakumar titled "Developing Teaching Material for E-learning Environment". It was published in the Journal of Education and Practice focuses research on the effectiveness of a design and quality on the development of teaching materials for learning in a network. The superior value of this study lies in the effectiveness of learning time and extensive learning outreach from the idea of E-Learning development offered [16].

Mbete in his research on "Khazanah Verbal sebagai Representasi Pengetahuan Lokal, Fungsi Pemeliharaan, dan Pelestarian Lingkungan Bahasa" find the verbal meanings and vocabularies in the forms of lexicon units contained in Waijewa and Kodi Language which are rich in meanings and functions, including sociological, biological, and ideological function well associated in both linguistic speeches [17]. The research conducted by Aron Meko Mbete somewhat has similarity and difference with those of this research. The difference is located on the lingistic data and problems. The research conducted by Mbete has taken the data in the form of textual data of Waijewa and Kodi language related to the natural environment, while 
this research has taken the written data in the form of textual parts of conservation news in mass media.

Yuniawan, Masrukhi, Urip, Ahmad, Utomo conducted a study on "An Insightful Discourses Model of Ecolinguistic Based-Conservation Values as an Enrichment of Environmental Education Course". The study produced a discourse model of ecolinguistic insightful conservation values as an enrichment of teaching material to Environmental Education subject [18]. And then, Yuniawan, Retnoningsih, Siroj conducted the study titled "The Development of Thematic Dictionary of Eco-Technic Dictionary of Ecology as an Enrichment of Conservation Education Subject" and concluded that (1) the test on experts of thematic ecolinguistic ecolexicon dictionary as an enrichment of teaching course material in Conservation Education course wherein its respondent included lecturers and experts, received a score of 85.71 (very good); (2) a test on the effectiveness of ecolinguistic thematic ecolexicon dictionary as an enrichment of Conservation Education subject matter on social humanities- clustered students received a score of 85.87 (very good); and (3) a test on the effectiveness of ecolinguistic thematic ecolexicon dictionary as an enrichment of education subject teaching material Conservation in scientific-clustered students received a score of 85.56 (very good) [19].

These studies serve as a theoretical and methodological framework used as a reference to analyze our text with conservation insight as an enrichment of environmental literacy in elementary school students. For this reason, the focus of this research is to find out the need for text insightful to conservation pillar as an environmental literacy for elementary school student. This study aims to analyze the level of requirement for text insightful to conservation pillar as an enrichment of environmental literacy to elementary school student.

\section{Method}

This research uses Research and Development approach by adapting Borg and Gall Model [20] and Sugiyono [21]. We analyze the data on the requirement level for insightful text of conservation pillar as an environmental literacy for students in elementary school. The source of data includes informants, activities, and documents. Our informants are students and teachers of UNNES campus at Sekaran, Patemon, Kalisegoro, Mangunsari, and Ngijo areas. We employed several data collection techniques which include (1) focus group discussion, (2) interview, (3) observation, and (4) questionnaire. Our research instruments are: (1) requirement analysis questionnaire, (2) questionnaire on criteria for text-insightful to conservation pillar as an environmental literacy in elementary school, and (3) questionnaire on level of readability. Finally, this research uses limited and expert testing for data analysis.

\section{Result and Discussion}

\subsection{The Requirement Level of Conservation-Insightful Text as an Enrichment of Environmental Literacy in Primary School Student}

The result shows that the requirement level for conservation-insightful text as an enrichment environmental literacy of elementary school student leads to the following aspects: content, readability, presentation and graphics, and motivation. The number of sample students in this study is fifty. Every student could choose more than one answer and add 
answers deemed necessary. Therefore, the percentage presented is the percentage of number of choices compared to the total number of students.

\subsubsection{The Aspect of Content}

Based on the research data, the requirement level for conservation-insightful texts as an enrichment of environmental literacy in elementary school students for the aspect of content is as follows:

Table 1. The Aspects of Content of Conservation-Insightful Text

\begin{tabular}{|c|c|c|c|}
\hline \multirow[t]{2}{*}{ Indicator } & \multicolumn{3}{|c|}{ Scale $(\%)$} \\
\hline & $\begin{array}{c}\text { Very } \\
\text { necessary }\end{array}$ & Necessary & $\begin{array}{c}\text { Un- } \\
\text { necessary }\end{array}$ \\
\hline $\begin{array}{l}\text { Conservation-insightful texts containing environmental } \\
\text { knowledge. }\end{array}$ & 88 & 12 & 0 \\
\hline $\begin{array}{l}\text { Conservation-insightful texts contain values that can be } \\
\text { used to build environmentally caring behavior. }\end{array}$ & 86 & 14 & 0 \\
\hline $\begin{array}{l}\text { Conservation-insightful texts suitable in learning } \\
\text { materials }\end{array}$ & 88 & 12 & 0 \\
\hline $\begin{array}{l}\text { There is a section in the text with insight into } \\
\text { conservation knowledge on environmental } \\
\text { conservation. }\end{array}$ & 85 & 15 & 0 \\
\hline $\begin{array}{l}\text { There is a section in the text with conservation- } \\
\text { insightful which emphasizes appreciation on the values } \\
\text { of environmental preservation. }\end{array}$ & 87 & 13 & 0 \\
\hline $\begin{array}{l}\text { Conservation-insightful texts contain conservation } \\
\text { concept. }\end{array}$ & 85 & 15 & 0 \\
\hline $\begin{array}{l}\text { There is a section in the conservation-insightful texts } \\
\text { that reviews conservation of values and character. }\end{array}$ & 88 & 12 & 0 \\
\hline $\begin{array}{l}\text { There is a section in the conservation-insightful text } \\
\text { that covers arts and cultural conservation. }\end{array}$ & 87 & 13 & 0 \\
\hline $\begin{array}{l}\text { There is a section in the conservation-insightful text } \\
\text { that reviews the conservation of natural resources and } \\
\text { the environment. }\end{array}$ & 86 & 14 & 0 \\
\hline $\begin{array}{l}\text { Conservation-insightful texts have been able to build an } \\
\text { understanding of conservation of values and character. }\end{array}$ & 88 & 12 & 0 \\
\hline $\begin{array}{l}\text { Conservation-insightful texts have been able to build an } \\
\text { understanding of art and culture conservation. }\end{array}$ & 87 & 13 & 0 \\
\hline $\begin{array}{l}\text { Conservation-insightful texts have been able to build an } \\
\text { understanding of natural resources and environment } \\
\text { conservation. }\end{array}$ & 85 & 15 & 0 \\
\hline $\begin{array}{l}\text { Conservation-insightful texts are complemented by } \\
\text { assignments for students to apply the conservation } \\
\text { concept. }\end{array}$ & 88 & 12 & 0 \\
\hline $\begin{array}{l}\text { Conservation-insightful texts have been supported by } \\
\text { up-to-date data related to environmental and social } \\
\text { issues. }\end{array}$ & 87 & 13 & 0 \\
\hline $\begin{array}{l}\text { Conservation-insightful texts have been supported by } \\
\text { real examples (best practice) in conservation } \\
\text { management in various fields. }\end{array}$ & 88 & 12 & 0 \\
\hline
\end{tabular}


The above data shows that the average answers lie at a high percentage score, i.e. above $85 \%$ very necessary. This implies that very-necessary conservation-insightful texts pay attention to the three major pillars of conservation, namely: (1) pillars of value and character, (2) pillars of art and culture, and (3) pillars of natural and environmental resources.

\subsubsection{The Aspect of Readability}

Based on the research data, the requirement level of textual as conservation-insightful as an environmental literacy enrichment of elementary school students in the aspects of readability is as follows:

Table 2. The Aspects of Readability of Conservation-Insightful Text

\begin{tabular}{lcc}
\hline \multicolumn{1}{c}{ Question } & Answer & Percentage \\
\hline So that the information submitted is clear and \\
$\begin{array}{l}\text { easily accepted, what kind of language is used in } \\
\text { the text with conservation insight? }\end{array}$
\end{tabular}

Based on the data in table 2, there are two kinds of languages used to convey information in conservation-insightful texts delivered to make them understandable and easily accepted. The two choices are formal and colloquial. Of the two choices, the formal language is the most dominant choice. They also have several reasons which include: (1) easy to understand by the students, (2) formal, (3) normally using formal language. Next, there are two choices of words in the conservation-insightful text that the students wish to use. Those choices use a lot of scientific terms and colloquial terms.

Of these two terms, colloquial language terms is a more dominant choice. They offered several reasons, including: (1) easily accepted, understood, comprehended, (2) in order to understand the term and can be interpreted and easily understood by the reader, and (3) communicative.

\subsubsection{The Aspects of Presentation and Graphic}

Based on the research data, the level of textual requirement of conservation-insightful as an environmental literacy enrichment of elementary school students in the aspects of presentation and graphics is as follows.

Table 3. The Aspects of Conservation-Based Text Presentation and Graphic

\begin{tabular}{llc}
\hline \multicolumn{1}{c}{ Question } & \multicolumn{1}{c}{ Answer } & Percentage \\
\hline $\begin{array}{l}\text { What conservation-insightful text } \\
\text { interests you? }\end{array}$ & $\begin{array}{l}\text { Conservation-insightful texts with bright cover } \\
\text { colors and lively cover designs }\end{array}$ & $3 \%$ \\
\cline { 2 - 3 } & $\begin{array}{l}\text { Conservation-insightful text with bright cover } \\
\text { colors and a lively cover design with illustration } \\
\text { pictures }\end{array}$ & $12 \%$ \\
\hline
\end{tabular}




\begin{tabular}{|c|c|c|}
\hline & $\begin{array}{l}\text { Conservation-insightful text with a simple cover } \\
\text { design, equipped with illustrated images }\end{array}$ & $85 \%$ \\
\hline \multirow{2}{*}{$\begin{array}{l}\text { What coloring for drawing } \\
\text { illustrations do you like? }\end{array}$} & Colorful & $80 \%$ \\
\hline & Black and white & $20 \%$ \\
\hline \multirow[t]{4}{*}{ Which font size do you like? } & 16 & $2 \%$ \\
\hline & 12 & $88 \%$ \\
\hline & 11 & $10 \%$ \\
\hline & 9 & 0 \\
\hline \multirow[t]{3}{*}{ Which font do you want? } & 1. Times New Roman & $80 \%$ \\
\hline & 2. Arial & $15 \%$ \\
\hline & 3. Tahoma & $5 \%$ \\
\hline
\end{tabular}

Based on the above data, students had several choices i.e. bright conservation-insightful textbooks with lively cover designs, books with bright cover and lively cover designs equipped with illustrated images, books with simple equipped with cover designs and illustrated images. This shows that textbook of conservation- insightful with a simple cover design and illustrated images was the dominant choice. They also offered several reasons, including: (1) to make the book interesting to read, (2) cover design illustration is more aesthetically pleasing to the eye, (3) better use image illustrations to make it easily understood, (4) simple images and colors but attractive and not boring.

Furthermore, for coloring of image illustrations, they had the choice between colorful and black and white. Of these choices, colorful illustration was the dominant choice. They also offered several reasons, including: (1) increased interest in reading, (2) to make it more attractive, (3) the color not too striking, (4) look s more visible/real, and (5) more modern. With regard to font sizes for books of conservation-insightful text, they had several choices, namely: $16,12,11$, and 9 . Among these sizes/fonts, size 12 is the dominant choice. They also offered several reasons, including: (1) size 12 fits better, not too big and not too small, (2) it is generally used, (3) standard, (4) normal, (5) it is in accordance with the systematics of writing, and (6) easy to read.

Next, with regard to the preferred font for content material of conservation-insightful texts, they had several choices, namely: Times New Roman, Arial, and Tahoma. Among these fonts, Times New Roman is the dominant choice. They also offered several reasons, including: (1) it is easier to read, (2) more formal, ( 3) modest, (4) standard, and (5) more official.

\subsubsection{The Aspects of Motivation}

Based on the research data, the requirement level of conservation-insightful text as an environmental literacy enrichment of elementary school students on motivational aspects is as follows.

Table 4. The Aspect of Student Motivation

\begin{tabular}{llc}
\hline \multicolumn{1}{c}{ Question } & \multicolumn{1}{c}{ Answer } & Percentage \\
\hline \multirow{2}{*}{$\begin{array}{l}\text { What things do you do when } \\
\text { studying at }\end{array}$} & Listen to explanation & $85 \%$ \\
\cline { 2 - 3 } school? & Record the material provided & $35 \%$ \\
\cline { 2 - 3 } & Read the material given & $45 \%$ \\
\cline { 2 - 3 } & Work on evaluation question & $80 \%$ \\
\cline { 2 - 3 } & Actively asking about information & $10 \%$ \\
\hline
\end{tabular}




\begin{tabular}{|c|c|c|}
\hline & \multicolumn{2}{|l|}{ that is unclear } \\
\hline & Actively answer question & $15 \%$ \\
\hline & Direct practice & $20 \%$ \\
\hline & Be quiet & $1 \%$ \\
\hline \multirow{4}{*}{$\begin{array}{l}\text { How do the teachers teach the } \\
\text { material you } \\
\text { like? }\end{array}$} & Lecture & $75 \%$ \\
\hline & Take notes & $15 \%$ \\
\hline & Discussion & $50 \%)$ \\
\hline & $\begin{array}{l}\text { Accompanied with example of } \\
\text { modeling from the text }\end{array}$ & $75 \%$ \\
\hline
\end{tabular}

Based on the data in table 4, the students' learning style varies greatly. They did a number of activities such as: listening to explanations, taking notes on the lecture, reading the course material, working on evaluation question, actively asking question on unclear subject, actively answering question, direct practice, and being silent. Among these activities, listening to teacher's explanation and working on evaluation questions are the dominant choices. They also offered several reasons, including: (1) to better understanding the material, (2) getting broader insight, (3) enriching knowledge/course material.

In addition, students were very lacking in terms of actively asking the teacher on material that is unclear and lacking in terms of actively answering questions raised by the teacher. This is due to the lack of direct practice and examples. Next, based on these data, the students had several preferences on teacher's teaching method. They preferred that the teacher teaches in the following methods: lecture, notes, discussion, with examples of modeling from the text. Among these methods, lecture and lecture with direct examples were the dominant choices. They offered several reasons, including: (1) to easily understand the context explained, (2) easy to understand the course material, (3) get a example directly, (4) it's both nice and demanded to be active, (5) to know how to learn, (6) balanced between theory and practice, (7) increased interest in listening to course material

\section{Discussion}

Based on the analysis result, conservation-oriented texts played a strategic role to enrich elementary students' environmental literacy. This could be explained as follows. Enviornmental problems could not be dealt with only by repositioning the relationship between human and their natural environment, rather it should also be attempted by reorienting values, ethics and norms of life which were then reflected on a collection action, as well as by restructuring social relationship between individuals, individuals and groups, groups and other groups, and between groups and larger organizations. It was at this point as well that the education world was demanded to be capable of developing a perspective relevant to environmental issues. Believing on a theory which states that there is a correlation between education and environment conservation, the use of conservation-oriented texts could then be a relevant and prospective alternative to enrich elementary students' environmental literacy. This was in line with Curriculum 2013 which used texts as its basis of teaching and learning in general. In particular, language teaching and learning was expected to be an introduction to various other courses which were related one to another. This went hand to hand with the attempt to use conservation-oriented texts as teaching materials.

Conservation-oriented texts presented information on three pillars, namely: values and characters, arts and culture, and natural resources and environment. Using these conservation- 
oriented texts, students not just studied what text types and other language lessons were, rather they also learned natural sciences, social sciences, environment-related techonologies, and character values.

In addition to being used as a language teaching and learning material, conservationoriented texts could also be used as readings in supporting the Gerakan Literasi Sekolah (GLS) or School Literacy Movement program. In order to generate high-quality humans who could be synergistic in their socialization to make the environment and nature more beatiful, ecoliteracy had been highly important. The main objective of ecoliteracy lied in the descontruction of anti-ecology self-concept to green self-concept. The term "self" in this context had expanded meaning, which embedded it as an organism self, i.e. the self with an intact meaning. The green self concept came from what Joanna Macy, an ecologist, called "greening of the self". In line with the effort of internalizing this "greening of the self" concept, a real effort was need to promote ecoliteracy as a new lifestyle. Therefore, upon reading and criticizing conservation-oriented texts, it was expected that gradually the ecoliteracy concept and the concept of importance of maintaining the ecosystem would be internalized within each one of the students.

Furthermore, these conservation-oriented texts also had eight conservation character values, namely inspiring, humanistic, caring, innovative, creative, sportive, honest, and fair. These eight values were based by religious value.

The first conservation value was inspiring as reflected in the self of students who constantly had ideas to be prepared to do something, either deliberately or not, based on the ideas springing into their brains under any situation and circumstance.

The humanistic conservation value became a wonderful color of human life and their humanity since thanks to the existence of humanistic value, human life became wonderful that it fulfilled the aesthetic value in their life. The humanistic value was reflected in students' attitude of willingly respecting others, constantly expecting and striving for the manifestation of better life socialization based on the principles of humanity.

The caring conservation value served to strengthen the belief that caring to others was a worth-nurturing noble value, since caring to others became the real evidence of greatest masterpiece of human civilization, namely love. Students were expected to have this caring to others character value which served as a proof that love still existed, since no greater power in the world could beat love and the real embodiment of existence of this love was a care. The caring value constituted an energy to pay heed, attention, and consideration to others. However, only caring to others did not suffice anymore, one should also care to the environment where human beings lived. Caring to environment was the attitude and action of always striving for preventing environmental damage and developing attempts to remedy the environmental damages which had happend as a result of human's hands. Social caring was attitude and action of constantly wanting to help others and the community in need.

The innovative conservation value couls strengthen the belief that "nothing is entirely new, since what actually exists is innovation". The innovative value became an evidence that an attempt was actually made by students to upgrade. Thanks to this innovative value, students were encouraged to constantly produce innovative works to make human life better. The innovative value was the ability to exploit thoughts, imagination, stimulants and the environment to generate upgraded products.

The creative conservation value was reflected on the ability to create. This implied the creation of creative and conservation-oriented technologies in such a way that it could give as much benefit as possible to the community of Indonesia, in particular, and the world in 
general. Being creative, students could find new ways of solving the problems of the nation and humanity by always providing alternative settlement to any problem.

The sportive conservation value was the ability to act like a gentleman and be honest. Sportiveness meant being fair to opponents, willing to acknowledge others' win, strength, and rightness or their own loss, weakness and wrongness. Thus, sportive was one's mental attitude which showed an act of a gentleman, honesty, fairness and willingness to acknowledge others' strength and success, and willingness to acknowledge one's own loss. The honest conservation value was the attitude which was based on the attempt of making themselves reliable in what they said and did. Being honest had such meanings as being trustworthy, faithful, sincere, persistent and consistent.

The fair conservation value meant to take impartial action, only upholding the truth, and did not harmed either other nor oneself. Fairness meant everything related to attitude and action in interpersonal relationship, fairness contained a demand for people to treat others based on their rights and duties, this treatment did not discriminate nor favor a certain party; rather, everyone was treated according to their rights and duties. Fairness was also defined as a condition where everyone in their life as a part of a community, a nation and a state, received what they were entitled to, thus they could perform their duties.

These eight values were covered in conservation-oriented texts. This fact made the conservation-oriented texts important since they could improve students' competence in their disciplines as well as shape their attitudes and personalities. This could be implemented through the use of conservation-oriented text to enrich elementary students' literacy.

\section{Conclusion}

The requirement level for conservation-insightful text as an environmental literacy enrichment in elementary school students was acquired based on inputs from the students and teachers. The aspects developed in the text were conservation-insightful, namely: content, readability, presentation and graphics, and motivation. The aspect of book content needs to consider the three pillars of conservation, namely: (1) pillar of value and character, (2) pillar of art and culture, and (3) pillar of natural and environmental resources. The aspect of readability needs to present a variety of formal and colloquial language, the choice of words in conservation- insightful texts using both daily/colloquial and scientific terms. The aspect of presentation and graphic needs to pay attention to the design of simple, conservationinsightful textbook with illustrations, colorful illustrations, font of Times New Roman with size 12. Finally, the aspect of motivation needs to pay attention to the lecture and teaching method with direct examples by the teacher because this method is the most popular among the students.

The results of this study can be used to prepare conservation-insightful texts as the element in enriching the environmental literacy for elementary school students. In addition, they can be also be used to improve the quality of learning in elementary school. 


\section{Acknowledgment}

The author would like to thank Prof. Dr. Fathur Rokhman, M.Hum from Semarang State University; Prof. Dr. Rustono, M. Hum. from Semarang State University; Prof. Dr. Ida Zulaeha, M. Hum. from Semarang State University; Prof. Dr. Aron Meko Mbete; LP2M Semarang State University; Primary School Students and Teachers in the Sekaran area, Patemon, Kalisegoro, Mangunsari, and Ngijo.

\section{References}

[1] Leader Williams, N., Adams, W.M. \& Smith, R.J. (eds). Trade-offs in Conservation: Deciding What to Save. John Wiley \& Sons, Chichester, UK. (2011)

[2] Peraturan Rektor Universitas Negeri Semarang Nomor 6 Tahun 2017 tentang Spirit Konservasi UNNES. Semarang: UNNES.

[3] Mikulik, J dan M. Babina. "The Role of Universities in Environmental Management. Environmetal Study, Volume 18, No. 4, halaman 527-531. (2009)

[4] UNESCO. Development of Information Literacy: Through School Libraries in South-East Asia Countries. Bangkok: UNESCO. (2005).

[5] PIRLS. Assesment Framework (2nd ed.). Chestnut Hill, MA: Boton Colege. (2015).

[6] Rokhman, Fathur, dan kawan-kawan. "Rekayasa Bahasa sebagai Penguatan Pembudayaan Konservasi di UNNES". Laporan Penelitian. Semarang: UNNES. (2012).

[7] OECD. Education at a Glance 2013: OECD Indicators. Israel: OECD Publishing. ISBN 978-92-64-20104-0. http://dx.doi.org/10.1787/eag-2013-en . (2013)

[8] UNESCO. Development of Information Literacy: Through School Libraries in South-East Asia Countries. Bangkok: UNESCO. (2005).

[9] PIRLS. Assesment Framework (2nd ed.). Chestnut Hill, MA: Boton Colege. (2015).

[10] Halliday, M. A. K. dan Ruqaiya Hasan. Bahasa, Konteks dan Teks: Aspek- Aspek Bahasa dalam Pandangan Semiotik Sosial (Terjemahan Asruddin Barori Tou, dari judul asli: Language, Context, and Text: Aspect of Language in a Social Semiotic Perspective). Yogyakarta: Gadjah Mada University Press. (1992).

[11] Keraf, Sony A. Filsafat Lingkungan Hidup. Alam sebagai sebuah Sistem Kehidupan. Yogyakarta. Kanisius. (2014).

[12] [16] Krishnakumar and Jayakumar. "Developing Teaching Material for Elearning Environment”. Ni Journal of Education and Practice Vol 2, No. 8, 2011. (2011)

[13] [17] Mbete, Aron Meko. "Khazanah Verbal sebagai Representasi Pengetahuan Lokal, Fungsi Pemeliharaan, dan Pelestarian Lingkungan Bahasa”. A Research. Denpasar: Udayana University. (2012)

[14] [18] Yuniawan, Tommi, Masrukhi, Sri Rejeki, Tsabit, Asep Purwo Yudhi. Model Wacana Berwawasan Nilai-Nilai Konservasi Berbasis Ekolinguistik sebagai Pengayaan Materi Ajar Mata Kuliah Pendidikan Lingkungan Hidup. Laporan Penelitian Ditlitabmas Kemenristek Dikti. Jakarta. (2015, 2016) 
[15] [19] Yuniawan, Tommi, Amin Retnoningsih, M. Badrus Siroj. Model Pengembangan Kamus Ekoleksikon Tematik Berwawasan Ekolinguistik sebagai Pengayaan Materi Ajar Mata Kuliah Pendidikan Konservasi. Laporan Penelitian Ditlitabmas Kemenristek Dikti. Jakarta. (2017, 2018)

[20] Borg, Walter R., Meredith D. Gall. Educational Research: An Introduction. New York \& London: Longman. (1983)

[21] Sugiyono. Metode Penelitian Pendidikan Pendekatan Kuantitatif, Kualitatif, dan $R$ \& D. Bandung: Alfabeta. (2012) 